\author{
詹佳冰，陈琛，李华萍 ${ }^{*}$, 汪道文 ${ }^{*}$ \\ 华中科技大学同济医学院附属同济医院心血管内科, 暨湖北省心血管病遗传与分子机制重点实验室, 武汉 430030 \\ * 联系人, E-mail: dwwang@tjh.tjmu.edu.cn; 1hp@tjh.tjmu.edu.cn \\ 收稿日期: 2021-03-06; 接受日期: 2021-05-11; 网络版发表日期: 2021-09-10 \\ 国家自然基金(批准号: 81822002, 31771264, 31800973)资助
}

\begin{abstract}
摘要糖尿病是威胁人类健康的重大疾病之一. 随着我国经济的迅猛发展, 糖尿病患病率呈显著上升趋势, 而其 中 $80 \%$ 的糖尿病患者最终死于心血管并发症. 糖尿病心肌病是糖尿病最主要的心血管并发症. 多项临床研究表明, 强化血糖控制可以显著地减少糖尿病患者心肌梗死事件的发生, 但不能降低糖尿病患者因心力衰竭入院或死亡 的风险。这表明糖尿病患者曾经处于高血糖状态后，即使经过降糖治疗后血糖水平降低，仍易发生糖尿病相关的 心血管并发症，被称为高糖记忆(hyperglycaemic memory)现象. 本文就糖尿病心肌病中高糖记忆现象的机制研究 进行了综述.
\end{abstract}

关键词高血糖记忆, 糖尿病心肌病, 糖尿病, 心力衰竭

糖尿病是威胁人类健康的重大疾病之一，全球患 病率为 $4 \% \sim 17 \%$, 给社会和家庭带来了沉重的医疗和 经济负担. 最近的流行病学调查显示, 我国成年人糖 尿病患病率为 $11.6 \%$. 糖尿病会引起心、脑、肾、眼 等多器官功能障碍，其中 $80 \%$ 的糖尿病患者最终死于 心血管并发症. Framingham研究表明，糖尿病患者心 力衰竭的发病率明显高于非糖尿病患者，男性糖尿病 患者的心力衰竭发病率增高接近2倍，而女性糖尿病 患者的心力衰竭发病率增高 5 倍. 既往认为糖尿病通 过促进高血压及冠心病的发生，间接导致了心力衰 竭 ${ }^{[1]}$. 糖尿病引起的血管功能损伤被认为是糖尿病导 致心力衰竭的主要原因. 然而近年的一些研究发现, 即使在控制了冠状动脉疾病和高血压之后, 糖尿病仍 是心力衰竭的独立危险因素 ${ }^{[2-4]}$. 最近的研究认为, 糖
尿病引起的心力衰竭在很大程度上是由糖尿病直接损 伤心肌所导致的.

糖尿病心肌病(diabetic cardiomyopathy)的概念早 在1974年即被提出, 被认为是一种独立于高血压、冠 心病及其他原因, 由糖尿病导致的心脏结构和功能异

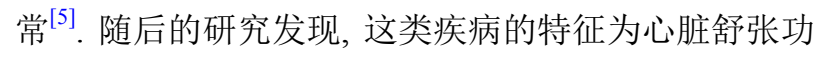
能下降和血管/微血管功能受损, 晚期则发展为全心功 能不全, 其病理学特征为心肌细胞肥大、间质纤维 化、毛细血管基底膜增厚、毛细微血管瘤和毛细血管 密度减少 ${ }^{[6,7]}$.

然而, 糖尿病心肌病目前尚无有效的治疗措施.

一直以来, 高血糖被认为是糖尿病心肌病发生与 发展的最主要因素, 高血糖能够激活多种下游的信号 通路, 例如PKC, MAPK, NF- $\mathrm{kB}$, SGLT2, O-GlcNAc和

引用格式: 詹佳冰, 陈琛, 李华萍, 等. 糖尿病心肌病中的高糖记忆现象及机制. 中国科学: 生命科学, 2022, 52: 151-160

Zhan J B, Chen C, Li H P, et al. Hyperglycaemic memory in diabetic cardiomyopathy (in Chinese). Sci Sin Vitae, 2022, 52: 151-160, doi: 10.1360/SSV2021-0020 
CREM, 进而导致心肌细胞调亡、RAAS系统激活和心 脏结构重塑等 ${ }^{[8]}$. 因此, 很多研究者将降糖治疗作为预 防和治疗糖尿病心肌病的关键措施. 然而, 许多大规模 的临床研究却发现，对于糖尿病合并心力衰竭的患者, 严格控制血糖并没有改善患者的总体心血管事件结 局. 例如, 2015年发表在Lancet上的研究总结了数个大 规模随机对照临床试验(ACCORD, ADVANCE, VADT 和UKPDS等 $)^{[9]}$, 旨在研究降糖治疗对糖尿病患者心血 管事件结局的影响. 结果表明, 强化血糖控制可以减少 糖尿病患者心肌梗死事件的发生，却没有降低患者因 心力衰竭入院或死亡的风险 ${ }^{[9,10]}$. 这种现象表明, 糖尿 病患者曾经处于高血糖状态后, 即使经过降糖治疗, 血 糖水平降低, 仍易发生糖尿病相关心血管并发症, 被称 为高糖记忆 (hyperglycaemic memory)现象. 本文将介 绍近年来高糖记忆现象的机制研究进展, 为进一步开 发防治糖尿病心肌病的新策略和药物提供理论和实验 依据.

\section{1 晚期糖基化终产物}

晚期糖基化终产物(advanced glycation end products，AGEs)，是指在非酶促条件下，蛋白质、氨基 酸、脂类或核酸等大分子物质的游离氨基与还原糖 (葡萄糖)的醛基经过缩合、重排、裂解、氧化修饰等 一系列化学反应形成的一组稳定的终末产物 ${ }^{[11]}$. AGEs产生的关键影响因素包括糖氧化蛋白代谢周 期、血糖水平以及氧化应激程度, 其中一种或多种出 现异常时均可导致AGEs的产生增加 ${ }^{[12]}$. 在某些非高 血糖状态下，如高血压导致的体内氧化应激水平升 高, 以及衰老组织中代谢周期较长的异常蛋白的累积 等，也可导致AGEs的形成 ${ }^{[13,14]}$. 衰老心肌中增加的 AGEs可通过损伤线粒体蛋白功能, 导致细胞内钻稳 态失调和氧化应激，损伤心肌细胞功能 ${ }^{[15]}$. 可见，在 非高血糖状态下形成的AGEs也可对心脏造成损伤. 尽管如此，高血糖仍是促使机体内生成AGEs最为重 要的原因之一. 高血糖能够使得一些重要蛋白质，例 如细胞外基质 IV 型胶原蛋白、层黏连蛋白等发生不 可逆性的AGEs修饰，AGEs能够交联细胞外基质和层 黏连蛋白, 降低心脏顺应性, 导致舒张功能障碍. 此外, AGEs还可以通过与其特异性细胞表面受体(receptor for AGEs, RAGE)或直接作用等方式激活细胞内部多 条信号通路，促发炎症反应、生成活性氧(reactive oxygen species, ROS)类物质、细胞自噬或调亡等病 理生理变化, 导致心脏结构和功能发生改变, 继而出 现心肌舒张功能减退 ${ }^{[11]}$.

在成纤维细胞中, AGEs/RAGE信号刺激炎症反 应相关基因 $T G F-\beta$ 的合成，促进成纤维细胞增殖及基 质蛋白的表达, 过多的胶原蛋白沉积导致心肌出现 纤维化、心脏顺应性降低及舒张功能障碍 ${ }^{[16]}$. 在巨 噬细胞中, AGEs显著增加巨噬细胞RAGE的表达, 激活 NF- $\kappa \mathrm{B}$ 通路，促进巨噬细胞向促炎型M1表型的 分化 ${ }^{[17]}$. 活化的巨噬细胞分泌多种炎症因子, 通过细 胞间交互作用促进成纤维细胞的增殖与分泌功能. 在糖尿病大鼠内皮细胞中升高的AGEs能够抑制内 皮细胞来源的一氧化氮 $(\mathrm{NO})$ 水平，导致血管的舒张 功能障碍. 此外, AGEs还通过蛋白激酶 $\mathrm{C}$ 途径抑制 $\mathrm{NO}$ 功能, 导致血小板的活化和聚集出现障碍, 引起 血管内微血栓的形成 ${ }^{[18]}$. 低密度脂蛋白(low density lipoprotein，LDL)经AGEs修饰后其血浆清除速率明 显下降，过多的LDL会导致内皮功能紊乱及动脉粥 样硬化的形成 ${ }^{[19]}$. Zoltowska等人 ${ }^{[20]}$ 发现, AGEs修饰 后的LDL能够显著增强血小板对包括ADP在内的各 种聚集剂的反应性，进一步引起血管内血栓形成和 内皮功能障碍. 在心肌细胞中, Wang等人 ${ }^{[21]}$ 研究表 明, AGEs通过抑制FK506-结合蛋白 12.6(FK506binding protein 12.6, FKBP12.6)与兰尼碱受体2(ryanodine receptor 2, RyR2)的相互作用, 使心肌细胞内 钲离子浓度升高, 线粒体膜电位降低, 诱导心肌细胞 调亡, 最终导致心肌收缩和舒张功能障碍. 类似的研 究也发现, 钻通道关键蛋白SERCA2被AGEs修饰后 功能会出现异常, 导致心肌细胞内䥻离子紊乱, 引起 舒张功能障碍 ${ }^{[22,23]}$. 此外, AGEs也可以通过蛋白激 酶 $\mathrm{C}$ 通路直接激活线粒体 $\mathrm{ROS}$ 的生成, 引起心肌细胞 的调亡 ${ }^{[24]}$.

值得注意的是, 有研究表明, 由于生成AGEs的一 系列非酶糖基化反应(Maillard反应)的终末阶段是不 可逆的，而且经Maillard反应生成的AGEs修饰的蛋白， 如糖化的纤维蛋白原和胶原蛋白, 性质更稳定, 难以被 生物降解 ${ }^{[25,26]}$; 因此, 即使在高糖刺激去除后, 蛋白质 的AGEs修饰仍将持续存在 ${ }^{[11]}$. 综上所述，蛋白质的 AGEs修饰可能为高糖记忆现象的重要发病机制之一 (图1). 


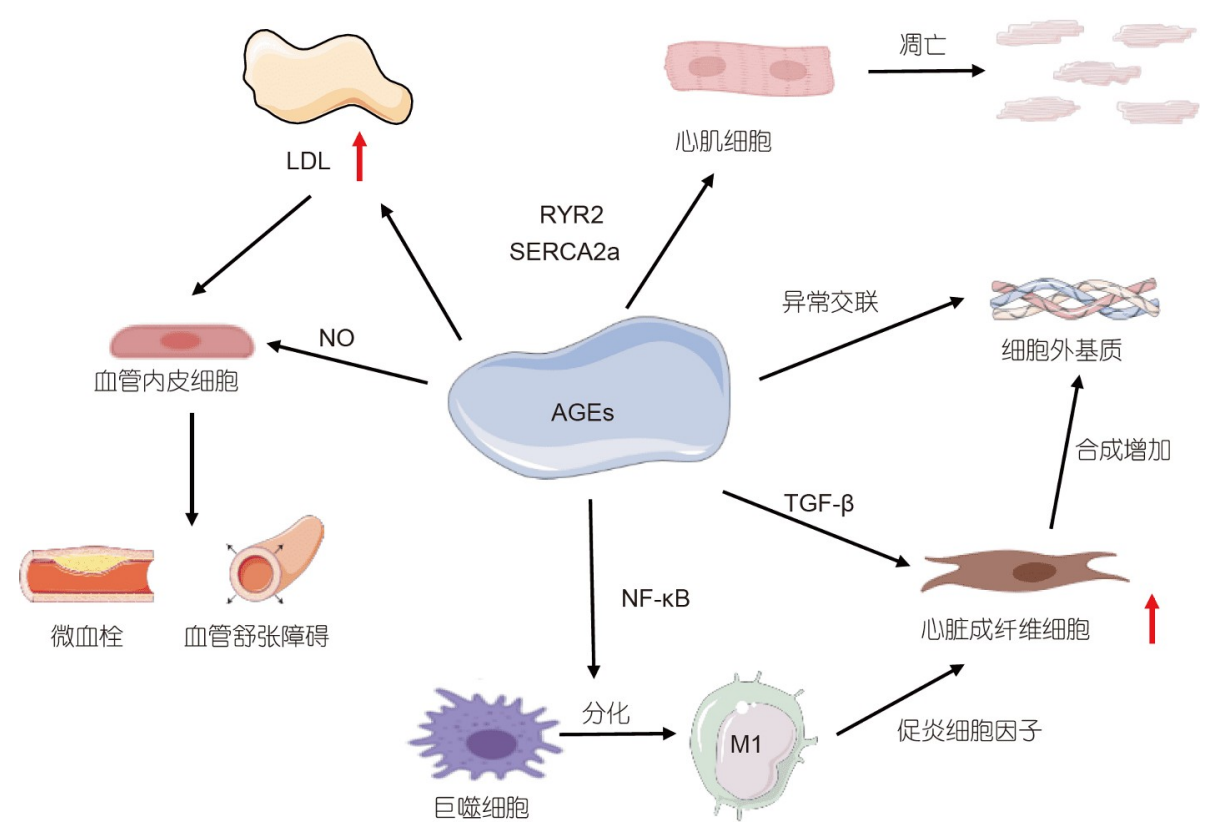

图 1 晚期糖基化终产物通过在多种细胞类型中参与不同的信号通路, 对糖尿病心肌病的发生及发展起到推动作用

Figure 1 AGEs promote the genesis and progression of diabetic cardiomyopathy by participating in a variety of signal pathways in different cell types

\section{2 microRNAs}

microRNAs(miRNAs) 是近年来新发现的一类具有 重要基因表达调控作用的非编码小RNA. 成熟miRNAs一般通过碱基互补配对原则与其靶mRNAs的 $3^{\prime}$ 端 非翻译区(untranslated region, UTR)序列完全或不完全 互补结合, 降解mRNAs或抑制mRNAs的翻译 ${ }^{[27]}$. 实际 上,一种miRNA能够靶向数百种的mRNA, 并以此为基 础调控众多在功能上相关的基因的表达模式 ${ }^{[28]}$. 大量 的研究表明, miRNAs可通过参与多种生物学进程, 如 自噬、氧化应激、细胞调亡、脂质沉积等 ${ }^{[29,30]}$, 在肿 瘤、代谢性疾病、肾脏疾病及心脑血管疾病等多种病 理生理状态下起到重要的调控作用 ${ }^{[30 \sim 33]}$. Zhong等

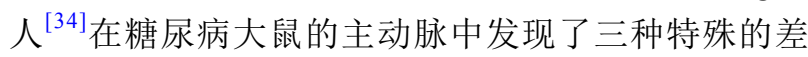
异表达的miRNAs(miR-125b，miR-29a-3p和miR-146a$5 p$ ). 与对照组相比, 这三种miRNAs在胰岛素治疗的 大鼠主动脉中的表达发生了显著变化. 他们进一步揭 示了在人主动脉内皮细胞中, miR-125b对TNF- $\alpha$ 诱导 的蛋白 3 (TNF- $\alpha$ induced protein 3, TNFAIP3)以及miR146a-5p 对TNF受体相关因子6(TNF receptor-associated factor 6, TRAF6) 和IL-1受体相关激酶1(IRAK1)的直接 调节作用. 即使在血糖水平恢复正常后, 这三个靶基因
(TNFAIP3, TRAF6和IRAK1)的蛋白质水平的变化仍然 持续存在, 但这种变化可以通过敲低miR-125b或过表 达miR-146a-5p 来恢复. Strycharz等人 ${ }^{[35]}$ 进行的另一项 研究表明, 在脂肪细胞发育过程中给予短暂的高糖刺 激, 可导致成熟的脂肪细胞中的miRNAs表达发生变 化, 其表达谱与长期暴露于高糖环境的脂肪细胞的表 达谱相似. 而Peng等人 ${ }^{[36]}$ 发现, 高糖诱导的视网膜色 素上皮细胞中 miR-204的上调和赖氨酸脱乙酰基酶 (SIRT1)的下调可在脱离高糖环境后得以持续存在, 这 导致内质网(endoplasmic reticulum, ER)应激和随后细 胞调亡.

Costantino等人 ${ }^{[37]}$ 发现, 在链脲佐菌素(streptozotocin, STZ) 诱导的 I 型糖尿病小鼠心脏中, 有316种miRNAs的表达出现了异常, 其中上调的有209种，下调的 有107种. 有意思的是, 经过降糖治疗恢复正常血糖以 后, 这316种miRNAs中的268种在小鼠心脏中的表达仍 然异常. 下游信号通路分析结果表明, 持续表达异常的 这268种miRNAs靶向的基因与多种信号通路有关, 包 括细胞凋亡(miR-320b, miR-378和miR-34a), 纤维化 (miR-125b, miR-150, miR-199a, miR-29b和miR30a), 心肌肥厚(miR-1, miR-150, miR-199a, miR-133a, miR214, miR-29a, miR-125b, miR-221和miR-212), 自噬 
(miR-133a，miR-221，miR-212和miR30a)，氧化应激 (miR-221， miR-146a， miR-34a， miR-210， miR-19b, $\operatorname{miR} 125 b, \operatorname{miR} 27 \mathrm{a}$ 和 $m i R-155)$ 和心力衰竭( $m i R-423$, miR-499和miR-199a)。这项研究表明，血糖控制并不 能完全逆转由高血糖引起的心脏中miRNAs表达的改 变, 这为心肌的高糖记忆现象提供了一种新的机制研 究思路. 最近, Cosentino团队 ${ }^{[38]}$ 发现, JunD(转录因子 活化蛋白1(activator protein-1, AP-1)家族的成员之一) 通过抗氧化应激在高血糖或ROS引起的心肌功能障碍 中起到保护作用. 他们的结果进一步揭示，JunD的表 达水平同时受其基因启动子区域的高甲基化以及 miR-673的翻译抑制作用的调控.

最近, 本团队 ${ }^{[27]}$ 的研究发现, 在糖尿病小鼠心肌中 异常升高的miR-320通过在细胞核中促进Ago2与RNA 聚合酶 II 的结合，进而增强CD36基因的转录; 升高的 CD36导致心肌细胞摄取过多的中性脂肪酸, 从而增加 心脏的脂质毒性, 促进心肌细胞调亡, 损伤心功能而导 致糖尿病心肌病. 著名脂质代谢专家Junichi Sadoshima 教授认为, miR-320对CD36转录的选择性上调, 是一种 增加脂质摄取而不影响脂质氧化水平的新机制. miR320 在胞浆中通过结合Ago2形成RNA诱导沉默复合物 发挥RNA干扰作用，而在糖尿病状态下细胞核内 miR320 上调, 与Ago2在细胞核内形成了特殊复合物, 从而 发挥转录激活作用 ${ }^{[32]}$. 此外, 本团队 ${ }^{[39]}$ 的另一项研究 显示，在糖尿病小鼠的心脏中过表达miR-30可以抑制
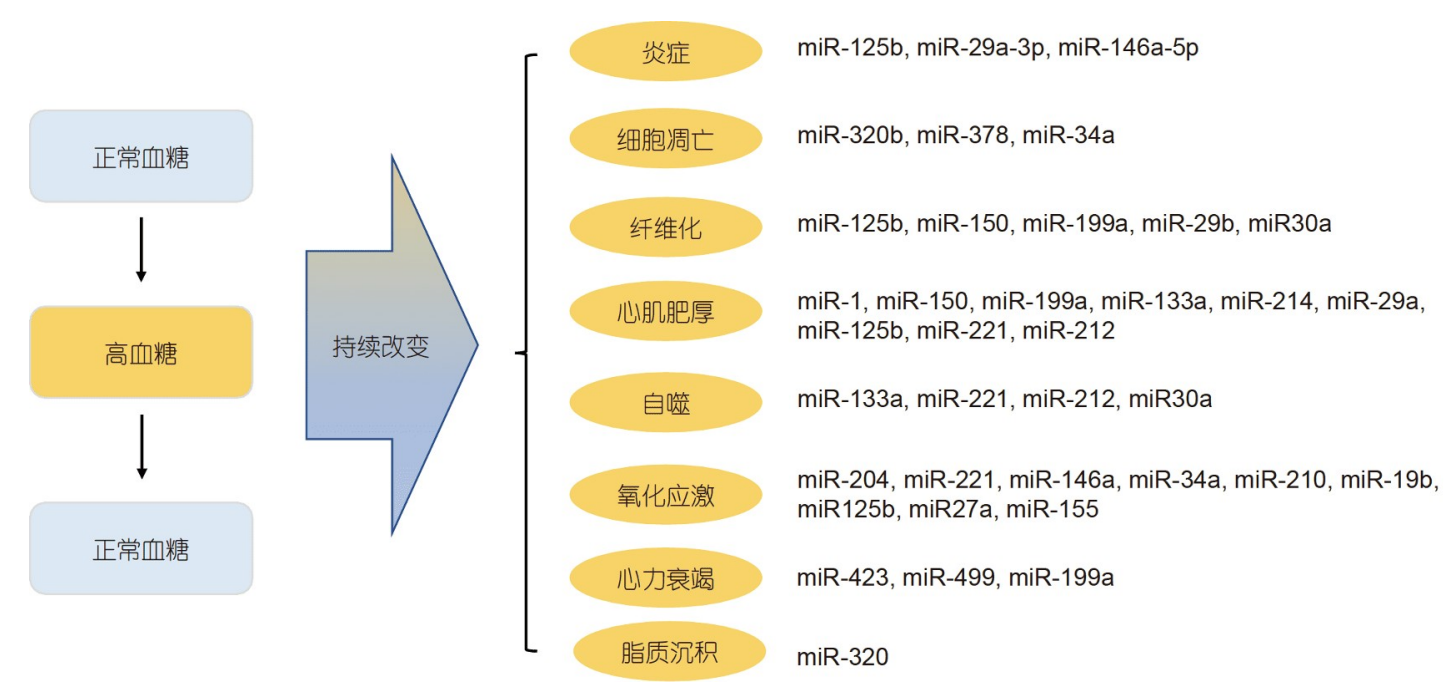

图 2 具有高糖记忆性的miRNAs参与包括心肌肥厚、纤维化、氧化应激在内的多种病理生理过程

Figure 2 Persistently dysregulated miRNAs in diabetes even after normoglycemia are involved in various pathophysiological processes including myocardial hypertrophy, fibrosis, and oxidative stress 
p $66^{\text {Shc }}$-ROS通路是参与高糖记忆现象的重要机制之 - ${ }^{[44]}$. Ihnat等人 ${ }^{[45]}$ 发现, 高糖干预的人脐静脉内皮细 胞(human umbilical vein endothelial cells, HUVEC)在恢 复低糖培养一周后, 氧化应激标志物和促氧化酶 $(\mathrm{PKC} \beta$ 和 $\mathrm{NAD}(\mathrm{P}) \mathrm{H}$ 氧化酶) 的上调仍持续存在. Lee等 人 $^{[46]}$ 的研究揭示了在高血糖症小鼠的主动脉内皮中, 转谷氨酰胺酶2(TGase 2)活化与ROS构成了一个恶性 循环, 这个恶性循环在血糖水平恢复正常后仍持续存 在, 但却可以通过口服Cys(一种TGase抑制剂)或NAC $(R O S$ 清除剂 $\mathrm{N}$-乙酰半胱氨酸)中止.

在心肌细胞中, NADPH氧化酶是影响ROS生成的 关键酶 ${ }^{[47]}$. 糖尿病时, 心肌细胞的NADPH氧化酶活性 明显增加, 导致ROS的过度产生, 引起心肌细胞调 $亡^{[48]}$. 而本才队 ${ }^{[49]}$ 最近的研究也发现, 在糖尿病心肌 病小鼠的心脏组织中, 线粒体ROS产生明显增加, 同 时线粒体内 miR-92a-2-5p和let-7b-5p在糖尿病心肌病 小鼠心脏中的表达明显下降. 线粒体内 miR-92a-2-5p 和let-7b-5p的下调直接降低线粒体关键蛋白细胞色素 $\mathrm{b}$ (cytochrome-b, Cytb)的表达, 引起线粒体ROS产生增 加, 最终导致糖尿病心肌病的发生发展. Costantino等 人 $^{[37]}$ 的研究中也发现let-7家族参与了高糖记忆现象. 由于线粒体ROS的过度产生也可以反过来调控 miRNAs的表达 ${ }^{[50,51]}$, 因此, 线粒体ROS与miRNAs可能会 形成独立的恶性循环, 在高糖恢复正常后继续存在, 是 糖尿病心肌病中高糖记忆现象的发病机制之一(图3).

\section{4 组蛋白修饰和DNA甲基化}

近年来, 研究者发现DNA甲基化和组蛋白修饰是 高糖记忆现象的重要机制之一. 启动子区 $\mathrm{CpG}$ 岛二核 苷酸的低甲基化通常与基因激活有关, 而 $\mathrm{CpG}$ 岛二核 苷酸的甲基化会干扰转录因子与启动子区的结合，而 促进甲基 $\mathrm{CpG}$ 结合域蛋白的结合, 后者会进一步募集 组蛋白脱乙酰基酶, 从而抑制基因转录 ${ }^{[52]}$. 组蛋白尾 部的赖氨酸残基也可以发生甲基化修饰, 这是一个非 常复杂的过程，包括单甲基化、二甲基化或三甲基化， 这些甲基化通常在特定区域内聚集，导致染色体重构 形成不同的结构域和功能域, 此过程可引起基因的转 录激活 ${ }^{[33]}$.

El-Osta等人 ${ }^{[54]}$ 研究发现, 瞬时的高糖刺激能够使 内皮细胞中核因子 $\kappa \mathrm{B}(\mathrm{NF}-\kappa \mathrm{B}) \mathrm{p} 65$ 亚基启动子区域产

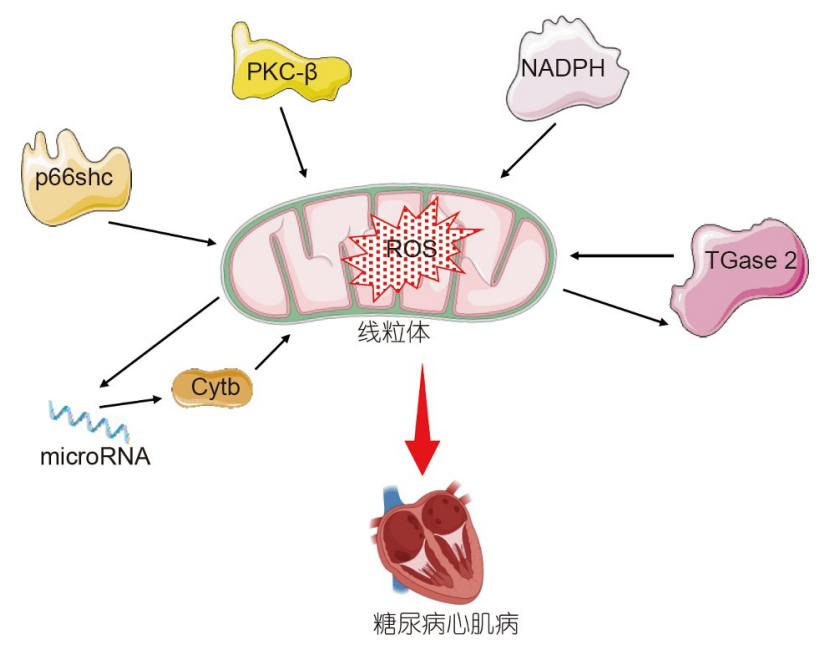

图 3 高糖刺激条件下, 细胞内多种氧化应激相关的酶类及 miRNA作用于线粒体, 促使线粒体活性氧的产生增加, 导致 糖尿病心肌病的发生及发展

Figure 3 Upon high glucose exposure, oxidative stress related miRNAs and enzymes in cells upregulate the production of mitochondria-derived ROS, which further promote the genesis and progression of diabetic cardiomyopathy

生持续的表观遗传修饰. 其作用机制为高血糖产生的 过量ROS通过甲基转移酶Set7/9使组蛋白H3 赖氨酸 4 氨基残基(histone $\mathrm{H} 3$ lysine, 4H3K4)发生单甲基化修 饰 ${ }^{[55]}$. H3K4的甲基化是一种关键的翻译后修饰, 有利 于哺乳动物的基因转录激活. 高糖使得 NF- $\mathrm{\kappa B}$ p 65 亚基 的组蛋白H3结合近端启动子区发生此类甲基化, 导致 炎症反应被持续性激活 ${ }^{[56]}$, 而且在去除高糖干预后, 这种炎症激活仍然存在 ${ }^{[54]}$. 此外, 组蛋白 H3 赖氨酸-9 三甲基化(histone H3 Lys-9 trimethylation, H3K9me3) 修饰也参与了高糖诱导的炎症激活和代谢记忆现 象 ${ }^{[57]}$. 心肌细胞中, 高糖刺激使得组蛋白甲基转移酶 Suv39h1与IL-6启动子的结合减少, IL-6启动子区域 H3K9me3修饰程度的降低引起了 IL-6的转录激活. 高 糖所导致的IL-6启动子区域H3K9me3水平的降低是不 可逆的, 而对心肌细胞的调亡、线粒体功能障碍的影 响却是可逆的 ${ }^{[57]}$. 炎症细胞中, 高糖处理增加了单核 细胞内共激活因子HATsCBP对 $\mathrm{p} 300$ 的募集, 使得炎症 基因启动子区域发生了 $\mathrm{H} 3 \mathrm{Kac}$ 和 $\mathrm{H} 4 \mathrm{Kac}$ 修饰, 染色质 结构重塑, 促进了炎症基因表达 ${ }^{[58]}$. 此外, Miao等人 ${ }^{[59]}$ 通过对糖尿病患者与健康对照者的淋巴细胞进行表观 基因组分析，发现多种与炎症和自身免疫相关的基因 发生了 $\mathrm{H} 3 \mathrm{~K} 9 \mathrm{me} 2$ 修饰, 并与糖尿病并发症的进展息息 相关. 
虽然组蛋白赖氨酸甲基化修饰是可逆的，但它仍 然是稳定的表观遗传修饰方式之一，其中一些组蛋白 赖氨酸残基位点由甲基化状态向去甲基化状态转换的 效率极低 ${ }^{[60,61]}$, 因此可能是导致高糖记忆的关键因素 之一(图4). 值得注意的是, 有部分表观遗传修饰酶的 表达水平在短暂的高糖刺激后也发生了持续的改变. 例如, Zheng等人 ${ }^{[62]}$ 发现，高糖刺激下调了牛视网膜毛 细血管内皮细胞(bovine retinal capillary endothelial cells，BRECs)中NAD依赖性脱乙酰酶sirtuin-1(SITR1) 的水平，然而恢复正常葡萄糖水平培养并不能使 SIRT1的水平有所回复. 也有文献报道, 升高的葡萄糖 降低了HUVECs中的赖氨酸甲基转移酶SET8蛋白，后 者在血糖水平回复正常后仍处于较低水平 ${ }^{[63]}$.

\section{5 其他机制}

糖尿病患者常伴有多重代谢紊乱，例如脂代谢紊 乱、肥胖、胰岛素抵抗等, 单纯的降糖治疗无法完全 缓解脂代谢紊乱和胰岛素抵抗对心脏的损害. 除了高 血糖，过量的脂肪酸也会引起脂毒性及心肌细胞凋亡, 促进糖尿病心肌病的发生发展 ${ }^{[27,32]}$. 更重要的是, 脂质 超载通常能够在各种组织中引起低水平炎症, 导致组 织的胰岛素抵抗，进一步促进糖尿病的发展. 脂肪组 织, 尤其是肥大的脂肪细胞或功能异常的脂肪组织, 被认为是肥胖人群体内的主要炎症因子来源, 可通过
分泌细胞因子趋化免疫细胞，并诱导其极化为促炎表

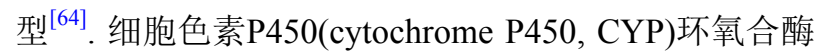
(CYP2J2)在体内的产物花生四烯酸 (epoxyeicosatrienoic acids, EETs) 已被证实具有重要的抗炎、抗调亡作 用. 而本团队 ${ }^{[65]}$ 近期的一项研究发现, 在糖尿病小鼠 心脏特异性过表达CYP2J2能够显著改善心脏的收缩 及舒张功能. 值得注意的是, CYP2J2的心脏特异性过 表达也显著降低了血浆葡萄糖和胰岛素水平, 有效地 改善了糖尿病小鼠体内的代谢紊乱. 因此, 对糖尿病 患者体内的代谢紊乱和低水平炎症同时进行干预治疗 可能是防治糖尿病心肌损害的一种思路.

此外, 有临床研究表明, 降糖药物的副作用也可能 使得糖尿病患者即使经过降糖治疗后血糖水平降低至 正常范围, 仍易发生糖尿病相关心血管并发症 ${ }^{[9]}$. 从机 制上来看, 所有降低血糖的药物, 都可能会对心脏功能 产生不利影响. 而且药物引发的低血糖发作可引起交 感神经系统激活和心率增加, 可能会导致血栓的形成 和心律失常, 进一步加重心室重构和心功能障碍. 例 如, 临床常用的降糖药物胰岛素, 能够增强近端小管 内的钠钾 $(\mathrm{Na} / \mathrm{K})$ ATP酶和碳酸氢钠共转运体 $(\mathrm{NBCe} 1)$ 的活性, 从而增加钠的重吸收, 引起水钠潴留及心功能 障碍 ${ }^{[9,66,67]}$.

因此, 除了细胞本身对高糖刺激的记忆特性之外, 降糖药物的副作用也可能在其中起到推波助澜的 作用.

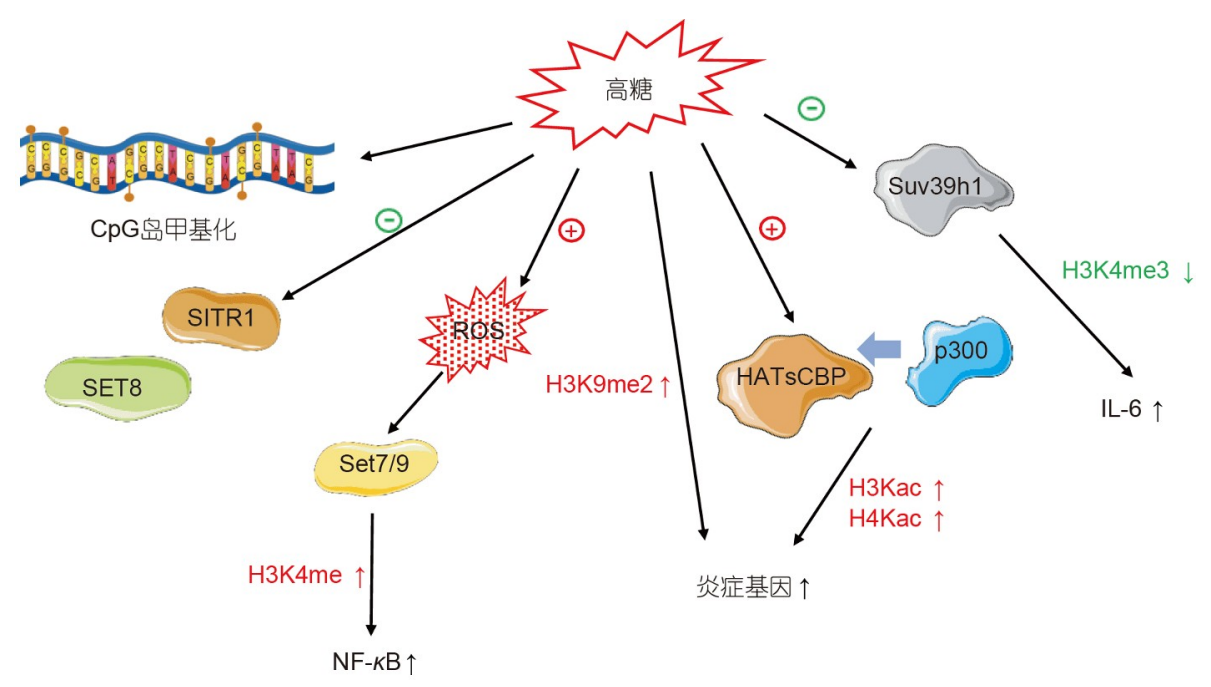

图 4 高糖刺激通过影响细胞内的DNA甲基化水平或组蛋白修饰酶的含量及活性, 对相应基因的表达水平产生持续性的调控 Figure 4 Hyperglycemia dysregulates the levels of DNA methylation or the content and activity of histone modifying enzymes, which then consistently change the expression levels of corresponding genes 


\section{6 总结与展望}

目前, 高糖记忆现象的机制仍未完全清楚. 已有 的研究表明, AGEs、miRNA、氧化应激和表观遗传 修饰等机制均参与其中. 然而, 这些机制并不是孤立 存在, 而是形成一个错综复杂的网络, 互相调控, 形 成恶性循环. 高糖引起的代谢异常引起线粒体氧化 应激. ROS生成的增加抑制了糖酵解酶甘油醛-3-磷 酸脱氢酶(glyceraldehyde-3-phosphate dehydrogenase, GADPH)活性, 糖酵解中间产物的积累激活了多 元醇和己糖胺途径，引起PKC- $\beta$ 通路活化和AGEs的 形成 ${ }^{[68,69]}$. 此外, ROS也可引起组蛋白的多种翻译后 修饰，包括乙酰化、甲基化、磷酸化、泛素化修饰 等. 降糖治疗后，即使葡萄糖代谢通路会恢复正常， ROS的产生减少，但表观遗传的修饰大多数是不可 逆的，因而引起致病基因(包括ROS激活相关基因)的 持续异常, 最终引起细胞功能障碍的进行性加

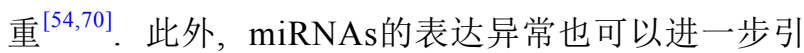
起线粒体功能障碍及 ROS 的激活 ${ }^{[49]}$. 上述的这些致 病分子形成了一个错综复杂、环环相扣的网络. 这
些发病机制中, 哪些分子是最为关键的起始因素, 目 前尚不清楚. 因此, 需要进一步进行严密设计的研究, 以揭示糖尿病心肌病最早出现的信号分子及关键异 常通路.

高糖记忆现象不仅发生在糖尿病心肌病中，也存 在于糖尿病肾病及糖尿病视网膜病变中, 即降糖治疗 后血糖恢复正常，但各种糖尿病并发症仍然继续进 展 ${ }^{[40,71]}$. 糖尿病对不同器官的损伤机制不同, 出现功 能障碍的靶细胞种类也不同. 例如，糖尿病肾病和视 网膜病变中，内皮细胞的高糖记忆性起主要作用. 而 糖尿病心肌病中, 多种细胞, 例如心肌细胞、心肌微 血管内皮细胞、成纤维细胞、免疫细胞可能共同参与 到高糖记忆的发病机制中. 此外, 以往的研究表明, 降 糖治疗可以明显改善糖尿病患者发生冠状动脉疾病的 风险, 却无法改善心力衰竭的发生风险 ${ }^{[9]}$, 也提示高糖 记忆现象在不同的器官和细胞中可能有不同的发病机 制. 因此, 未来的研究需要着重探索高糖记忆性在不同 器官和细胞中的独特机制以及细胞-细胞间的交互作 用. 深入揭示高糖记忆现象的时空变化规律将为糖尿 病并发症的防治提供重要的思路.

\section{参考文献}

1 Fang Z Y, Prins J B, Marwick T H. Diabetic cardiomyopathy: evidence, mechanisms, and therapeutic implications. Endocr Rev, 2004, 25: 543567

2 Fonarow G C. An approach to heart failure and diabetes mellitus. Am J Cardiol, 2005, 96: 47-52

3 Haffner S, Taegtmeyer H. Epidemic obesity and the metabolic syndrome. Circulation, 2003, 108: 1541-1545

4 Hsueh W, Abel E D, Breslow J L, et al. Recipes for creating animal models of diabetic cardiovascular disease. Circ Res, 2007, 100: 1415-1427

5 Hamby R I, Zoneraich S, Sherman L. Diabetic cardiomyopathy. JAMA, 1974, 229: 1749

6 Cosson S, Kevorkian J P. Left ventricular diastolic dysfunction: an early sign of diabetic cardiomyopathy? Diabetes Metab, 2003, 29: 455-466

7 Murray C J, Richards M A, Newton J N, et al. UK health performance: findings of the Global Burden of Disease Study 2010. Lancet, 2013, 381: $997-1020$

8 Jia G, Hill M A, Sowers J R. Diabetic cardiomyopathy: An update of mechanisms contributing to this clinical entity. Circ Res, 2018, 122: 624638

9 Gilbert R E, Krum H. Heart failure in diabetes: effects of anti-hyperglycaemic drug therapy. Lancet, 2015, 385: 2107-2117

10 Turnbull F M, Abraira C, Anderson R J, et al. Intensive glucose control and macrovascular outcomes in type 2 diabetes. Diabetologia, 2009, 52: $2288-2298$

11 Brownlee M. Glycation products and the pathogenesis of diabetic complications. Diabetes Care, 1992, 15: 1835-1843

12 Goldin A, Beckman J A, Schmidt A M, et al. Advanced glycation end products: sparking the development of diabetic vascular injury. Circulation, 2006, 114: 597-605

13 Ruiz-Meana M, Minguet M, Bou-Teen D, et al. Ryanodine receptor glycation favors mitochondrial damage in the senescent heart. Circulation, 2019, 139: 949-964

14 Nożyński J, Zakliczyński M, Konecka-Mrowka D, et al. Advanced glycation end product accumulation in the cardiomyocytes of heart failure 
patients with and without diabetes. Ann Transplant, 2012, 17: 53-61

15 Barandalla M, Haucke E, Fischer B, et al. Comparative analysis of AGE and RAGE levels in human somatic and embryonic stem cells under $\mathrm{H}_{2} \mathrm{O}_{2}$-induced noncytotoxic oxidative stress conditions. Oxid Med Cell Longev, 2017, 2017: 1-14

16 Oldfield M D, Bach L A, Forbes J M, et al. Advanced glycation end products cause epithelial-myofibroblast transdifferentiation via the receptor for advanced glycation end products (RAGE). J Clin Invest, 2001, 108: 1853-1863

17 Jin X, Yao T, Zhou Z, et al. Advanced glycation end products enhance macrophages polarization into M1 phenotype through activating RAGE/ NF- $\kappa$ B pathway. Biomed Res Int, 2015, 2015: 1-12

18 Bucala R, Tracey K J, Cerami A. Advanced glycosylation products quench nitric oxide and mediate defective endothelium-dependent vasodilatation in experimental diabetes. J Clin Invest, 1991, 87: 432-438

19 Bucala R, Mitchell R, Arnold K, et al. Identification of the major site of apolipoprotein B modification by advanced glycosylation end products blocking uptake by the low density lipoprotein receptor. J Biol Chem, 1995, 270: 10828-10832

20 Zoltowska M, Delvin E, Ziv E, et al. Impact of in vivo glycation of LDL on platelet aggregation and monocyte chemotaxis in diabetic psammomys obesus. Lipids, 2004, 39: 81-85

21 Wang J, Tang Z, Zhang Y, et al. Matrine alleviates AGEs-induced cardiac dysfunctions by attenuating calcium overload via reducing ryanodine receptor 2 activity. Eur J Pharmacol, 2019, 842: 118-124

22 Tian C, Alomar F, Moore C J, et al. Reactive carbonyl species and their roles in sarcoplasmic reticulum $\mathrm{Ca}^{2+}$ cycling defect in the diabetic heart. Heart Fail Rev, 2014, 19: 101-112

23 Hamilton S, Terentyev D. Altered intracellular calcium homeostasis and arrhythmogenesis in the aged heart. Int J Mol Sci, 2019, $20: 2386$

24 Yang Y C, Tsai C Y, Chen C L, et al. Pkc $\delta$ activation is involved in ROS-mediated mitochondrial dysfunction and apoptosis in cardiomyocytes exposed to advanced glycation end products (Ages). Aging Dis, 2018, 9: 647-663

25 Fishman S L, Sonmez H, Basman C, et al. The role of advanced glycation end-products in the development of coronary artery disease in patients with and without diabetes mellitus: a review. Mol Med, 2018, 24: 59

26 Chaudhuri J, Bains Y, Guha S, et al. The role of advanced glycation end products in aging and metabolic diseases: bridging association and causality. Cell Metab, 2018, 28: 337-352

27 Li H, Fan J, Zhao Y, et al. Nuclear miR-320 mediates diabetes-induced cardiac dysfunction by activating transcription of fatty acid metabolic genes to cause lipotoxicity in the heart. Circ Res, 2019, 125: 1106-1120

28 Lu T X, Rothenberg M E. MicroRNA. J Allergy Clin Immunol, 2018, 141: 1202-1207

29 Chen C, Yang S, Li H, et al. Mir30c is involved in diabetic cardiomyopathy through regulation of cardiac autophagy via BECN1. Mol Ther Nucleic Acids, 2017, 7: 127-139

30 Dai B, Li H, Fan J, et al. MiR-21 protected against diabetic cardiomyopathy induced diastolic dysfunction by targeting gelsolin. Cardiovasc Diabetol, 2018, 17: 123

31 Raupach A, Torregroza C, Niestegge J, et al. MiR-21-5p but not miR-1-3p expression is modulated by preconditioning in a rat model of myocardial infarction. Mol Biol Rep, 2020, 47: 6669-6677

32 Tong M, Sadoshima J. Nuclear miR-320 controls lipotoxicity. Circ Res, 2019, 125: 1121-1123

33 Li H, Fan J, Chen C, et al. Subcellular microRNAs in diabetic cardiomyopathy. Ann Transl Med, 2020, 8: 1602

34 Zhong X, Liao Y, Chen L, et al. The microRNAs in the pathogenesis of metabolic memory. Endocrinology, 2015, 156: 3157-3168

35 Strycharz J, Świderska E, Wróblewski A, et al. Hyperglycemia affects miRNAs expression pattern during adipogenesis of human visceral adipocytes-Is memorization involved? Nutrients, 2018, 10: 1774

36 Peng Q H, Tong P, Gu L M, et al. Astragalus polysaccharide attenuates metabolic memory-triggered ER stress and apoptosis via regulation of miR-204/SIRT1 axis in retinal pigment epithelial cells. Biosci Rep, 2020, 40

37 Costantino S, Paneni F, Lüscher T F, et al. MicroRNA profiling unveils hyperglycaemic memory in the diabetic heart. Eur Heart J, 2016, 37: $572-576$

38 Hussain S, Khan A W, Akhmedov A, et al. Hyperglycemia induces myocardial dysfunction via epigenetic regulation of JunD. Circ Res, 2020, 127: $1261-1273$

39 Yin Z, Zhao Y, He M, et al. MiR-30c/PGC-1 $\beta$ protects against diabetic cardiomyopathy via PPAR $\alpha$. Cardiovasc Diabetol, 2019, 18: 7

40 Matough F A, Budin S B, Hamid Z A, et al. The role of oxidative stress and antioxidants in diabetic complications. Sultan Qaboos Univ Med J, 
2012, 12: 5-18

41 Kuroki T, Isshiki K, King G L. Oxidative stress: the lead or supporting actor in the pathogenesis of diabetic complications. J Am Soc Nephrol, 2003, 14: S216-S220

42 Cosentino F, Francia P, Camici G G, et al. Final common molecular pathways of aging and cardiovascular disease: role of the p66 ${ }^{\text {Shc }}$ protein. Arterioscler Thromb Vasc Biol, 2008, 28: 622-628

43 Paneni F, Mocharla P, Akhmedov A, et al. Gene silencing of the mitochondrial adaptor $\mathrm{p} 66^{\text {Shc }}$ suppresses vascular hyperglycemic memory in diabetes. Circ Res, 2012, 111: 278-289

44 Paneni F, Volpe M, Lüscher T F, et al. SIRT1, p66 ${ }^{\text {Shc }}$, and Set7/9 in vascular hyperglycemic memory: bringing all the strands together. Diabetes, 2013, 62: 1800-1807

45 Ihnat M A, Thorpe J E, Kamat C D, et al. Reactive oxygen species mediate a cellular 'memory' of high glucose stress signalling. Diabetologia, 2007, 50: 1523-1531

46 Lee J Y, Lee Y J, Jeon H Y, et al. The vicious cycle between transglutaminase 2 and reactive oxygen species in hyperglycemic memory-induced endothelial dysfunction. FASEB J, 2019, 33: 12655-12667

47 Isabelle M, Vergeade A, Moritz F, et al. NADPH oxidase inhibition prevents cocaine-induced up-regulation of xanthine oxidoreductase and cardiac dysfunction. J Mol Cell Cardiol, 2007, 42: 326-332

48 Wendt M C, Daiber A, Kleschyov A L, et al. Differential effects of diabetes on the expression of the gp91 ${ }^{\text {phox }}$ homologues nox 1 and nox4. Free Radic Biol Med, 2005, 39: 381-391

49 Li H, Dai B, Fan J, et al. The different roles of miRNA-92a-2-5p and let-7b-5p in mitochondrial translation in db/db mice. Mol Ther Nucleic Acids, 2019, 17: 424-435

50 Climent M, Viggiani G, Chen Y W, et al. MicroRNA and ROS crosstalk in cardiac and pulmonary diseases. Int J Mol Sci, 2020, 21: 4370

51 Carden T, Singh B, Mooga V, et al. Epigenetic modification of miR-663 controls mitochondria-to-nucleus retrograde signaling and tumor progression. J Biol Chem, 2017, 292: 20694-20706

52 Jayaraman S. Epigenetic mechanisms of metabolic memory in diabetes. Circ Res, 2012, 110: 1039-1041

53 Brasacchio D, Okabe J, Tikellis C, et al. Hyperglycemia induces a dynamic cooperativity of histone methylase and demethylase enzymes associated with gene-activating epigenetic marks that coexist on the lysine tail. Diabetes, 2009, 58: 1229-1236

54 El-Osta A, Brasacchio D, Yao D, et al. Transient high glucose causes persistent epigenetic changes and altered gene expression during subsequent normoglycemia. J Exp Med, 2008, 205: 2409-2417

55 Ruthenburg A J, Allis C D, Wysocka J. Methylation of lysine 4 on histone H3: intricacy of writing and reading a single epigenetic mark. Mol Cell, 2007, 25: 15-30

56 Okabe J, Orlowski C, Balcerczyk A, et al. Distinguishing hyperglycemic changes by Set7 in vascular endothelial cells. Circ Res, 2012, 110: $1067-1076$

57 Yu X Y, Geng Y J, Liang J L, et al. High levels of glucose induce "metabolic memory" in cardiomyocyte via epigenetic histone H3 lysine 9 methylation. Mol Biol Rep, 2012, 39: 8891-8898

58 Miao F, Gonzalo I G, Lanting L, et al. In vivo chromatin remodeling events leading to inflammatory gene transcription under diabetic conditions. J Biol Chem, 2004, 279: 18091-18097

59 Miao F, Smith D D, Zhang L, et al. Lymphocytes from patients with type 1 diabetes display a distinct profile of chromatin histone H3 lysine 9 dimethylation. Diabetes, 2008, 57: 3189-3198

60 Zee B M, Levin R S, Xu B, et al. In vivo residue-specific histone methylation dynamics. J Biol Chem, 2010, 285: 3341-3350

61 Greer E L, Shi Y. Histone methylation: a dynamic mark in health, disease and inheritance. Nat Rev Genet, 2012, 13: 343-357

62 Zheng Z, Chen H, Li J, et al. Sirtuin 1-mediated cellular metabolic memory of high glucose via the LKB1/AMPK/ROS pathway and therapeutic effects of metformin. Diabetes, 2012, 61: 217-228

63 Chen X, Wu Q, Jiang H, et al. SET8 is involved in the regulation of hyperglycemic memory in human umbilical endothelial cells. Acta Biochim Biophys Sin, 2018, 50: 635-642

64 Prattichizzo F, De Nigris V, Spiga R, et al. Inflammageing and metaflammation: The yin and yang of type 2 diabetes. Ageing Res Rev, 2018, 41: $1-17$

65 Ma B, Xiong X, Chen C, et al. Cardiac-specific overexpression of CYP2J2 attenuates diabetic cardiomyopathy in male streptozotocin-induced 
diabetic mice. Endocrinology, 2013, 154: 2843-2856

66

Ruiz O S, Qiu Y Y, Cardoso L R, et al. Regulation of the renal Na- $\mathrm{HCO}_{3}$ cotransporter: IX. Modulation by insulin, epidermal growth factor and carbachol. Regul Pept, 1998, 77: 155-161

67 Féraille E, Carranza M L, Rousselot M, et al. Insulin enhances sodium sensitivity of Na-K-ATPase in isolated rat proximal convoluted tubule. Am J Physiol, 1994, 267: F55-F62

Brownlee M. Biochemistry and molecular cell biology of diabetic complications. Nature, 2001, 414: 813-820

Bianchi C, Miccoli R, Del Prato S. Hyperglycemia and vascular metabolic memory: truth or fiction? Curr Diab Rep, 2013, 13: 403-410

Cooper M E, El-Osta A. Epigenetics: mechanisms and implications for diabetic complications. Circ Res, 2010, 107: 1403-1413

71 Schena F P, Gesualdo L. Pathogenetic mechanisms of diabetic nephropathy. J Am Soc Nephrol, 2005, 16: S30-S33

\title{
Hyperglycaemic memory in diabetic cardiomyopathy
}

\author{
ZHAN JiaBing, CHEN Chen, LI HuaPing \& WANG DaoWen \\ Hubei Key Laboratory of Genetics and Molecular Mechanisms of Cardiological Disorders, Division of Cardiology, Department of Internal Medicine,
} Tongji Hospital, Tongji Medical College, Huazhong University of Science and Technology, Wuhan 430030, China

Diabetes has become one of the major threats to human health worldwide. The prevalence of diabetes has accelerated significantly during the past decades with the rapid economic development in China. Cardiovascular disease accounts for $80 \%$ of the death among diabetic patients, while diabetic cardiomyopathy is one of the major diabetic cardiovascular complications. Of note, several clinical trials have demonstrated that intensive glycaemic control was able to mildly but significantly reduce the risk of myocardial infarction, but not sufficient to lower the risk of heart failure in diabetic patients. This phenomenon indicates that diabetic patients, who have been in a state of hyperglycemia, are prone to diabetes-related cardiovascular complications even after reverting to normoglycemia by hypoglycemic treatment, which is described as hyperglycemic memory (HGM). In this review, we briefly summarized the current mechanism of HGM in diabetic cardiomyopathy.

\section{hyperglycaemic memory, diabetic cardiomyopathy, diabetes, heart failure}

doi: $10.1360 /$ SSV-2021-0020 